


\title{
Systemic approach to the choice of optical methods of forensic examination of micro-objects
}

\author{
DOI: https://doi.org/10.46398/cuestpol.3969.35
}

\author{
Havryliuk Liudmyla * \\ Drozd Valentyna ** \\ Nenia Olena ${ }^{* * *}$ \\ Kyslyi Anatolii **** \\ Niebytov Andrii ******
}

\section{Abstract}

The aim of the article is to analyze theoretical and methodological provisions related to the definition of directions and principles of implementation of a systematic approach to the use of optical research methods, in particular micro-objects. Subject of research is substantiation and formulation of the classification characteristics of such systematic approach, considering the requirements of forensic techniques. Methodology: The study applies such methods of scientific knowledge as dialectical method, system and structural method, logic and legal method, methods of systematic analysis, logical method. Research results: The article studies the problematic issues of a systematic approach to the choice of scientific and technical methods and means for micro-object examination. Practical consequences: The authors argue that optical methods of the micro-object examination require classifying and systematizing to provide a holistic view of their potentials, as well as the nature of the information that can be obtained about the object being examined. Value / originality: The analysis of clarified classification characteristics and requirements for examination methods in

* Senior Researcher of Research Laboratory of Problems of Legal and Organizational Support of the Ministry Activities of State Research Institute of the MIA of Ukraine, Candidate of Legal Sciences, Kyiv, Ukraine. ORCID ID: https://orcid.org/oooo-0002-9441-4073. Email: luda.gavriljuk@gmail.com

** Head of the 3rd Research Department of Research Laboratory of Problems of Legal and Organizational Support of the Ministry Activities of State Research Institute of the MIA of Ukraine, Doctor of Law, Professor, Kyiv, Ukraine. ORCID ID: https://orcid.org/oooo-0002-7687-7138. Email: valusha. drozd@gmail.com

*** Head the Department, State Research Institute of the MIA of Ukraine, Candidate of Legal Sciences, Kyiv, Ukraine. ORCID ID: https://orcid.org/oooo-0oo1-9721-5718. Email: nenya2012@ukr.net

**** Doctor of Law, Professor, Director of the Educational and Scientific Law Institute named after the Prince Vladimir the Great of Interregional Academy of Personnel Management, Ukraine. ORCID ID: https://orcid.org/oooo-0002-4152-9539. Email: iapm@iapm.edu.ua

***** Doctor of Law, Associate Professor, Head of the Main Department of the National Police in the Kiev region, Ukraine. ORCID ID: https://orcid.org/oooo-0002-8493-3064. Email: obl_kyiv@kv.npu.gov.ua 
forensic science enables to propose the algorithm of the systemic approach to the creation of the open system classification of methods of micro-object examination and to make justified conclusions.

Keywords: criminal proceeding; micro-objects; criminological examinations; forensic examination; optical methods.

\section{Un enfoque sistemático para la elección de métodos ópticos. investigación forense de microobjetos}

\section{Resumen}

El objetivo del artículo es analizar las disposiciones teóricas y metodológicas relacionadas con la definición de direcciones y principios de implementación de un enfoque sistemático para el uso de métodos de investigación óptica, en particular micro objetos. El estudio aplica métodos de conocimiento científico tales como método dialéctico, método de sistema y estructural, método lógico y legal, métodos de análisis sistemático, método lógico. El artículo estudia las cuestiones problemáticas de un enfoque sistemático de la elección de métodos y medios científicos y técnicos para el examen de micro objetos. Los autores argumentan que los métodos ópticos del examen de micro objetos requieren una clasificación y sistematización con el fin de proporcionar una visión holística de sus potenciales, así como de la naturaleza de la información que se puede obtener sobre el objeto examinado. Se concluye que el análisis de las características de clasificación aclaradas y los requisitos para los métodos de examen en la ciencia forense permite proponer el algoritmo del enfoque sistémico para la creación de la clasificación de sistema abierto de métodos de examen de micro objetos y sacar conclusiones justificadas.

Palabras clave: proceso penal; micro objetos; exámenes criminológicos; examen forense; métodos ópticos.

\section{Introduction}

Ukraine is on the path of significant changes at the current stage of its development: the structure of economic relations is changing, new subjects of property and political activity are being formed, basic values, living arrangements are being transformed, the way of life and traditions are changing (Kyslyi et al., 2020). Therefore, the knowledge of criminals, for example how to conceal the traces of the crime, requires more up-to-date 
Havryliuk Liudmyla, Drozd Valentyna, Nenia Olena, Kyslyi Anatolii y Andrii Niebytov Systemic approach to the choice of optical methods of forensic examination of micro-objects

approaches and techniques to obtain tracing and evidentiary information. Therefore, it is increasingly important to use micro-objects to obtain forensic information that, because of their size, is difficult to destroy, falsify, to prevent their formation and remain at the scene of a criminal offence.

The main factor in improving the efficiency and effectiveness of the work with micro-objects, as well as the objectivity of the results obtained, is the knowledge of criminologists, in particular forensic examiners, regarding the existing examination methods, their potentials, as well as making the right choice of examination method.

The advance of science and technology constantly increases the possibilities of micro-object examination, thanks to the occurrence and introduction of new means and methods, in particular optical, which in comparison with other physical and chemical techniques have the advantage of non-destructive effect of optical radiation on the object being examined, highly informative and accurate.

The task of choosing a method of examination from the diversity of existing and new ones is quite complex, even based on the experience, logic, knowledge, and intuition of examiners, and it requires a scientific system approach.

The analysis of scientific sources suggests that the issue of the classification and systematization of methods of optical examination, of micro-objects, is not well studied. Some scientists, including forensic scientists, have identified specific groups of examination methods related to specific tasks and research areas.

The relevance of the topic under study is the need to define a criterion (classification characteristic) and a systematic mechanism for the establishment of an open system classification of existing optical methods for micro-object examination, which will ensure greater effectiveness of examiner's performance.

Thus, the aim of the article is the study of the areas and principles of implementing a systematic approach to the application of optical methods of examination, of micro-objects, with a view to extending the potentials of expert examinations, increasing their efficiency and objectivity.

\section{Methodology}

The methodological basis of this study is the system of general and special methods of scientific knowledge. The application of these methods is due to a systemic approach, which has enabled the study of the issues involved. 
The dialectic method enables to analyses the optical methods of microobject examination in a comprehensive manner, which objectively meets the requirements of examiner's performance and a comprehensive and impartial investigation of the circumstances of criminal proceedings. The systematic and structural method enables to consider optical methods of examination, of micro-objects, as a structured link in the system of sources of evidentiary information, to analyses their potentials and to propose their systematization. The logical and legal method enables to determine the place and role of micro-objects in criminal proceedings, in the system of evidence. The method of the systematic legal provision analysis is applied to analyze the legal provisions governing the use of specialized knowledge and technical means (including optical means) in criminal proceedings based on evidence and the needs of practice. The logical method of scientific knowledge is a basis for determining criteria for the choice of micro-object examination optical methods and their classification mechanism.

\section{Literature Review}

The use of micro-objects to solve the problems of criminal proceedings, which constitute evidence, is under focus by Klymenko (2008) (with regard to the use of micro-objects in the investigation of criminal offences); Kyrychenko (1994) (with regard to the fundamentals of forensic micrology); Saltevskyi (1980) (with regard to micro-objects and scent traces as sources of information in criminal proceedings), as well as the authors' team Korostashova et al., (2012) (with regard to the theoretical and practical basis of the use of micro-objects for criminal proceedings).

The use of scientific and technical methods for the investigation of physical evidence, including optical methods, as well as the legal basis and admissibility of their use, is under study in the works by Honcharenko (2011) (with regard to the requirements of forensic methods); Lisichenko (1979) (with regard to the use of methods of natural and technical sciences in crime investigation and forensics); Nenia (2010) (with regard to the legal and regulatory framework for the use of scientific and technological means and methods in forensic science).

The classification of examination methods, those based on the laws of optics, has been under focus of physicists, chemists, biologists, etc., and forensic scientists. To some extent, systematization of scientific and technical methods for the use in certain areas of forensic examination or in criminal proceedings have been made by scholars and practitioners such as: Davydova (2008) (with regard to the use of optical methods in forensic examination of materials, substances and items); Saltevskyi (1980) (with regard to the collection of forensic information by technical means during 
pre-trial investigations); Skrypko (2012) (with regard to micro-object examination of fibrous nature by means of polarization microscopy).

Prystupa and Zhuk (2005) have studied the issue of examination of soil elemental composition by methods of spectral analysis, including X-ray fluorescence analysis. Linch and Prahlow (2008) have investigated the use of optical methods for micro-object examination. Clarke and Eberhardt (2002) have provided an overview of and practical guide to the various computer-aided microscopical techniques used in materials science. The work by Lacey (1999) begins with the explanation of the basic techniques and goes on to describe current methods in chromosome microscopy, immunohistochemistry, fluorescence microscopy, image building and video microscopy.

The relevance of the topic under study is in the development of the issues of creating an open system classification of optical methods, forensic one, since micro-object examination has been out of the focus of scientists. This is due to several factors, first, the group of optical methods is numerous and with the development of science constantly increasing; second, the potentials and areas of the use of optical methods of examination are also wide and are considered in many technical, natural sciences and criminology; third, there is a lack of appropriate classification mechanism to be determined by criteria for optical methods of examination can be classified.

\section{Results and Discussion}

Any investigation, any evidence findings are based primarily on the investigation of the trace evidence of the crime.

The modern awareness of criminals of the potentials of traditional types of forensic examinations, such as identification of a person by fingerprints, firearms by traces on bullets and cartridges, an executor of a written text by handwriting, as well as the achievements in the portrait examination, makes the use of micro-objects for criminal proceedings increasingly relevant and promising.

This is primarily because of their small size, which generally makes it impossible for criminals to destroy them, to falsify, to prevent their occurrence at the scene of a criminal offence.

Despite their size, micro-objects are considered to be material evidence, as any other material traces of crime, if they contain the characteristics specified in article 98 of the Criminal Procedure Code of Ukraine (Law No. 1001-05, 1960). 
The size of the micro-objects, their multivariate nature (including the various aggregated states, that is, solid, liquid, gaseous) and their multifaceted links to the event of a criminal offence give rise to certain difficulties and limitations in their detection, seizing, recording, storing, and examining in order to obtain information for forensic purposes. Therefore, in almost all phases of pre-trial investigation (search operations and investigative actions, collection and preservation of evidence and expert examination), the use and application of scientific and technical methods and tools are important for operating with micro-objects (Klymenko, 2008).

While the use of scientific and technical methods and means is important at all stages of pre-trial investigation, it is expert examination, which is a crucial stage in the use of micro-objects in criminal proceedings, that constitutes evidence and requires the widest range of expertise, methods, and tools.

Moreover, most expert examinations of micro-objects involve optical methods.

Optical methods are methods based on the laws of optics concerning the nature of the propagation and interaction of the electromagnetic radiation of the optical range with the substance, and which enable to obtain comprehensive information concerning the properties and characteristics of the object(s) (Nenia, 2010).

The optical range encompasses electromagnetic radiation with wavelengths in the range from $10 \mathrm{~nm}$ to $1 \mu \mathrm{m}$ (Kruger et al., 1967). Optical methods have advantages over other physical methods of examination. The advantages of most of them are non-destructive effects of optical radiation on the object under examination, informativeness and high accuracy, the possibility to examine the physical and chemical properties with optical radiation of the object and so on.

The choice of scientific and technical forensic methods and means of examination, particularly optical ones, depends directly on the type of forensic expertise in which they are used. Therefore, from a methodological perspective, the question arises first of all with regard to the definition of forensic examinations that examine micro-objects, which is not only of theoretical but even more of practical importance.

It should be noted that micro-object examination is usually performed within forensic and engineering expertise, mainly the examination of materials, substances, and articles, biological, firearm and tool mark examinations (Order No. 53/5, 1998).

For example, the potential of optical methods is their use in expert examinations of firearms and ammunition, as well as explosive devices and explosives, to address identification, classification, diagnostic, 
situational issues, in particular methods of: observation, including optical microscopy, analysis - optical spectroscopy (emission spectral analysis; absorption spectral analysis; reflection spectroscopy, etc.) and methods of optical analysis, based on the measurement of the optical properties of the substance.

This is particularly relevant in view of the relentless military conflict in the Donbas, which is a major factor for increasing market in illegal firearms and the consequent increase in serious crimes, committed with firearms and explosive devices, including improvised explosive devices. This situation leads to a constant expansion of examination objects, most of which are specific and problematic for their examination. This in turn requires the development of new types of expertise and thereby new examination methods and the systematization of existing ones (Korotaiev, 2018).

In Ukraine and many countries of the world, one of the recent challenges in firearms examination is the extension of the scientific basis for comparing the marks on bullets and cartridges to determine their objectivity and subjectivity. The International Association of the Firearm and Tool Mark Examiners (AFTE) considered this issue as the key one, including not only the search for a scientific basis for potential errors identification, but also for the search and potential development of methods, that will improve the quality of expert examination. The United States President's Council of Advisors on Science and Technology (2016) addressed these issues in its report on forensics, in particular the forensic firearms examination.

Forensic (in particular expert) examination is a process of creativity, and this connects it to any scientific research. However, contrasting scientific research, forensic examination is formalised by the framework of criminal proceedings, making it orientated; the request to preserve and maintain the properties of the objects being examined and their features in the course of the examination. At the same time, the examiner should provide an objective, complete, reliable conclusion from the results of the examination, which requires the use of reliable methods and high-precision instruments ensuring the objectivity and reliability of the examination.

Considering that every year new examination methods are emerging, thanks to the integration and differentiation of scientific knowledge, the interpenetration of sciences and their methods, the combination of methods both homogeneous in nature, scientific bases and sources, as well as heterogeneous, arising and formulated in various fields of science, and thanks to the widespread introduction of nanotechnology, the examiner is faced with the corresponding task of constantly updating personal knowledge in this area and, thereby the constant need to choose the best method of examination. 
Since examination tasks can be solved by several different scientific and technical methods, the rational choice of a method usually takes into account the requirements for the final results of examinations, their accuracy and reliability, time limits, completeness of information and the like.

Moreover, the requirements for criminological (forensic) methods can be divided into two groups. The first group of requirements that are common to research in other scientific fields, including: validity, reliability, accuracy, safety, efficiency, cost-effectiveness, accessibility. The second group consists of the requirements related to the procedural status of the object examined, the method itself and the conclusion derived from the examination results: admissibility and ethics (Averianova et al., 2001).

According to Honcharenko (2011), only scientifically based means and methods can be used in investigative and expert work, provided the compliance with the principle of legality and conformity with generally acceptable ethical standards in our society.

Since examiner's report is one of the most important types of evidence, the assessment of its reliability is a very important element for all participants in criminal proceedings. For this purpose, along with the professional competence of the examiner, inter alia, the expediency and admissibility of applying specific examination methods should be verified.

An instrument for ensuring quality of work in all spheres of life is a system of universal methods, which are quality tools that constitute a quality management system for the respective field of activity, followed by accreditation by an independent accreditation body, validating the real level of technical competence, of forensic laboratories, and creating conditions for peer review of the results of their activities in different countries.

Active implementation of international quality standards, such as ISO/IEC 17025:2017 General requirements for the competence of testing and calibration laboratories (ISO, 2017) and ISO/IEC 17020 (2012) "Conformity assessment - Requirements for the operation of various types of bodies performing inspection" (ISO, 2012) in domestic forensic science institutions, in particular the MIA of Ukraine, began in 2010 when the State Scientific Research Forensic Centre (SSRFC) of the MIA of Ukraine in 2002 had acquired a membership of the European Network of Forensic Science Institutions (ENFSI). Since then, about 30 State specialized forensic science institutions in Ukraine have been accredited by these standards in various examination areas, including the MIA and the Ministry of Justice.

According to the ISO/IEC 17025 standard, laboratories examine the methods used to confirm their operability in laboratory conditions. Furthermore, the standard enables the application of methods developed by laboratories of an individual forensic science institution through a validation procedure for such method (Tatarnikova, 2017). 
For example, in 2018, the National Bureau of Expertise of the Republic of Armenia revealed the results of experimental studies and validation procedures for gas chromatography-mass spectrometry and UV spectrometric methods for quantification of buprenorphine. As a result, the Department of Physical, Technical and Chemical Research of the National Bureau of Expertise of the Republic of Armenia applied in the forensic practice two methods (including optical one) providing, respectively, a reliable quantification of buprenorphine (Tovmasian et al., 2005).

Therefore, the choice of the examination method is a difficult task, even based on the experience, logic, knowledge, and intuition of examiners. In our opinion, a scientific systems approach can help. In order to provide a holistic perspective on optical methods of examination, as well as to make the right choice, they should be systematized and classified.

This implies both methods already applied by examiners and those used in different fields of science and technology that can be used and adapted to effectively address examiner's tasks (Saltevskyi and Lukashevych, 1987). Literature review has not revealed any work related to summarizing optical methods of examination and to their fairly complete system classifying.

Scientists from various fields of expertise, including forensic scientists, inter alia, identify specific groups of examination methods, the systematization thereof is generally limited to classes, types, and sub-types of forensic examinations, taking into account the material and technical base of the institutions, where these examinations are carried out, as well as the nature of the information about the object being examined. A clear example of this is provided by the forensic examinations of materials, substances and products, where individual scientists have identified separate scientific methods, such as optical ones, in terms of the nature of the information obtained by methods: morphological analysis, material and substance composition analysis, substance structure analysis; the study of individual properties (Davydova, 2008; Levshin and Saletskyi, 1994; Mitrichev, 2003; Palenik, 2013; Pentin and Vilkov, 2003).

The use of examination methods may be regulated by the forms and types of examinations depending on the stage of the criminal proceedings (for example, in the collection of evidence, preliminary (extra-expert) examinations relating to non-processing, only non-destructive methods of optical microscopy are applied) and expert (procedural) methods which include optical methods of both observation and various analysis) (Davydova, 2008; Saltevskyi, 1980). The choice of method may also depend on the nature of the information to be obtained from the object being examined.

Therefore, the issue of increasing the potentials for expert examination is within the framework of the classification mechanism and in the 
identification of the criteria for the choice of method.

As noted above, examiners and criminologists consider that the main criterion (classification characteristics) for the selection of the examination method is the nature of the information to be obtained from the object being examined (Davydova, 2008; Mitrichev, 2003). In other words, what exists is the task, the method and a device that can solve this task. That is, a certain forensic science institution will use the scientific and technical means and methods with which it is equipped to examine a certain object (micro-object), considering the requirements of forensic science methods. We agree that this approach, especially from a practical perspective, is quite effective. However, this approach, in our view, is one-sided and limits the creative and search component of examiner's performance, and consequently limits the further development and expansion of forensic examination.

In order to improve existing examination methods and introduce new ones into expert practice, their potentials, advantages and disadvantages in comparison with other methods, as well as limitations in their application should be known in depth.

Such full knowledge of methods, particularly optical ones, as well as their comparison is impossible without a classification based on criteria by which these methods can be systematized (separated).

The physical phenomena that underlie them (for example, absorption, reflection, refraction, scattering, etc.) can be identified as the main criterion for the classification of optical methods (Nenia, 2010).

Moreover, it is this criterion that individual scientists use to systematize methods in analytical chemistry, biology, non-destructive testing (Clarke and Eberhardt 2002; Lacey, 1999).

However, an examiner does not always find the practical value of such classification appropriate. Not the last factor in the examiner's choice of examination method is questions put to the examiner, that is, we return to the information about the object being examined (micro-objects).

It should be noted that the highlighted criteria cannot, in our opinion, exist one without the other, as they are connected as communicating vessels.

Therefore, a systematization of optical methods for forensic examinations (of micro-objects in particular) should be based on comprehensive and harmonious combination of criteria, such as the essence of the physical process underlying the method; the nature of the information about the micro-object under examination (nature of the properties of the objects under examination) derived from the questions assigned to the forensic expert. 
Moreover, this system classification should be open and able to constantly adapt to the changes in science and technology, which implies its continual updating with new examination methods. To sum up, we propose to use a hierarchical method to systematize and classify optical methods of examination, which will further enable to establish a hierarchical relationship between different groups of optical methods of forensic examination of micro-objects.

Next, we consider the consistent approach to this tiered classification.

On the basis of the characteristic (criteria) of classification such as the physical phenomena underlying them, at the first level, the initial set of optical methods should be grouped into three subsets: light microscopy, based on the laws of geometric optics and wave theory of image formation, optical spectroscopy based on the absorption effect of electromagnetic radiation by atoms or molecules of the substance under examination, optical analysis methods based on the properties of light waves, such as polarization, absorption, coherence, refraction, etc. (Landsberg, 2000; Hel et al., 1998).

Moreover, this grouping of methods according to the first criterion simultaneously guides, although not yet detailed, but already in general terms, concerning the nature of the information that can be obtained from the object being examined (micro-object), that is, concerning the nature of the properties to be examined. For example, we know that optical microscopy techniques can determine the morphology of micro-object, its aggregate state, the degree of possible contamination and interaction with the material of the carrier, assess the natural color and luminescence, may establish its nature etc.

From our perspective, that is where the proposed criteria are harmoniously combined. At the second level of grouping of each of the proposed subsets, either this criterion (classification characteristic) or another can be chosen.

In our classification, we again choose the first criterion (classification characteristic) to group all three subsets of methods, in addition, the secondlevel grouping into the methods according to the physical phenomena underlying them, as at the first level, only in more detail, gives an idea of the nature of the properties, which can be examined.

Therefore, each subset of methods, grouping into a totality of subsets of methods, enables to describe in more details both the potentials of the respective method and the nature of the properties, which can be examined.

For example, further consideration of the first group of "Optical Spectroscopy" methods can group these methods at the second level into subsets: brightfield methods, darkfield methods, polarized light microscopy, 
interference contrast methods (interference microscopy) and others. Complete classification schemes are in the work (Nenia, 2016). Considering from this set of methods, for example, brightfield methods based on the fact that different parts of the object being examined reflect the light falling on them differently, while reflected rays have different intensity, this set of methods can be further divided into three ones: transmitted-light brightfield methods, reflected-light brightfield methods, and oblique illumination methods. Moreover, the title of each method describes it according to its potentials.

Therefore, grouping methods at each level simultaneously details the potentials of each of them, and therefore increases the guidance value for the examiner regarding the nature of the information that can be obtained from the object being examined (micro-objects) by a specific method of examination, as well as enables to identify other suitable examination methods.

This method systematization enables to choose not one but some methods to examine the same properties of the object being examined, to expand potentials of an examiner, moreover, enables to validate methods and techniques within the framework of ISO quality standards. This includes new examination methods applied to test the relevance of new methods' potentials declared.

Another factor in favour of such a systemic approach is the need for a forensic examiner to justify during the criminal proceeding, including the judicial one that the examination results are reliable and therefore constitute evidence. However, this is not possible without using methods with similar potentials that have already been validated.

\section{Conclusion}

Criminal law policy is a component of State policy in the area of crime control. The implementation of such policy and its effectiveness, role, place and significance depends on many factors, among which is application of up-to-date approaches and techniques to obtain tracing and evidentiary information (Vorobey et al., 2021).

Considering the increasing role of micro-objects in the detection and investigation of criminal offences and, at the same time, the specificity of their discovery, recording, seizure and preservation, examination and use as carriers of search and evidence information, it is relevant to improve the scientific and technical, as well as methodological, basis of work with them.

In particular, this applies to optical methods and micro-object examination means, used in both the extra-expert and expert stages of examination. 
Havryliuk Liudmyla, Drozd Valentyna, Nenia Olena, Kyslyi Anatolii y Andrii Niebytov 576 Systemic approach to the choice of optical methods of forensic examination of micro-objects

Initial and further understanding of the potentials of optical methods, in particular the degree of full potentials of micro-object examination, requires their systematization.

Any systematization is carried out for different purposes, specific to each branch, classification characteristics thereof are corresponding specific individual features or their complex.

In view of the determined and formalized aim of the study, a comprehensive and harmonious, in our opinion, combination of classification characteristics, such as the essence of the physical process underlying the method; the nature of the information about the micro-object being examined (nature of the properties of the objects being examined).

This approach to methods systematization has a great informational capacity, which will allow identifying a range of existing methods, providing a holistic view of their potentials, as well as revealing the nature of the information that can be obtained about the object being examined.

Such a systematization of methods can guide the examiner on the availability of other methods acceptable for examination, both those already used by examiners and new ones that can be borrowed or adapted from natural sciences.

This will allow the expansion of potentials of examiners' performance and at the same time increase the objectivity of examinations due to confirmation or disproval of the reliability of the examination results by another method with similar potentials.

\section{Bibliographical References}

AVERIANOVA, Tatiana, et al. 2001. Criminalistics. NORMA. Moscow. Available online. In: http://library.nlu.edu.ua/POLN_TEXT/KNIGI/BELKIN_ KRIM_2001.htm. Date of consultation:10/09/2020.

CLARKE, Ashley; EBERHARD, Colin 2002. "Microscopy Techniques for Materials Science" In: Woodhead Publishing, CRC Press. Cambridge, England.

DAVYDOVA, Olena. 2008. Forensic examinations of materials, substances and products. KNT. Kyiv, Ukraine.

HEL, Pavlo, et al. 1998. "Laboratory workshop on physics. Part 2: Oscillations and waves, optics" In: Vinnytsia State Technical University. Vinnytsia, Ukraine. 
HONCHARENKO, Vladlen. 2011. "Selected works" In: Precedent. Kyiv. Available online. In: http://e-books.aau.edu.ua/assets/books/ Goncharenko-selected-works.pdf. Date of consultation: 10/09/2020.

ISO. 2012. ISO/IEC 17020:2012 Conformity assessment - Requirements for the operation of various types of bodies performing inspection. Available online. In: http://www.tcdi.ru/standards/iso17020.php. Date of consultation: 10/09/2020.

ISO. 2017. ISO/IEC 17025 General requirements for the competence of testing and calibration laboratories. Available online. In: https://www.iso. org/files/live/sites/isoorg/files/store/en/PUB100424.pdf. Date of consultation: 10/09/2020.

KLYMENKO, Nina. 2008. The use of micro-objects in the investigation of crimes. In: SRECC of the MIA of Ukraine. Kyiv. Available online. In: http://consultant.parus.ua/?doc=oB46HE8F98\&abz=KLYLo. Date of consultation: 06/09/2020.

KOROSTASHOVA, Tetiana et al. 2012. Fundamentals of micro-objectology. In: Petro Mogyla Publishing House. Mykolaiv.

KOROTAIEV,Volodymyr. 2018. "Administrative and legal regulation of forensic firearms examination. PhD Dissertation" In: Dnipropetrovsk State University of Internal Affairs. Available online. In: https://dduvs.in.ua/ wp-content/uploads/files/Structure/science/rada/dissertations/25/2. pdf. Date of consultation: 06/09/2020.

KRUGER, Mark et al. 1967. Handbook of the designer of optical-mechanical devices. In: Mechanical Engineering. Lviv, Ukraine.

KYRYCHENKO, Aleksei. 1994. "Fundamentals of microobjectology" In: Lecture No. 3. Course of lectures on criminology: textbook. Petro Mohyla National University. Mykolaiv. Available online. In: http://library.mdu. edu.ua/Documents/Praci\%20vukladachiv/Institut_istorii_ta_prava/ Kirichenko/102_-_\%Do\%9A\%Do\%B8\%D1\%80\%Do\%B8\%D1\%87\%D o\%B5\%Do\%BD\%Do\%BA\%Do\%BE_\%Do\%9E._\%Do\%9o._\%Do\%9E \%D1\%81\%Do\%BD\%Do\%BE\% Do\%B2\%Do\%B8_\%Do\%BC\%D1\%96\% Do\%BA\%D1\%80\%Do\%BE\%Do\%BE\%Do\%B1\%E2\%80\%99\%D1\%94\% Do\%BA\%D1\%82\%Do\%BE\%Do\%BB\%Do\%BE\%Do\%B3\%D1\%96\%D1 \%97._\%Do\%9B\%Do\%B5\%Do\%BA\%D1\%86\% D1\%96\%D1\%8F_\%E2 \%84\%96_3._\%Do\%9A\%D1\%83\%D1\%80\%D1\%81_\%Do\%BB\%Do\%B5 \%Do\%BA\%D1\%86\%D1\%96\%Do\%B9_\%Do\%B7_\%Do\%BA\%D1\%80\% Do\%B8\%Do\%BC\%D1\%96\%Do\%BD\%Do\%Bo\%Do\%BB\%D1\% 96\%D1 \%81\%D1\%82\%Do\%B8\%Do\%BA\%Do\%B8.pdf. Date of consultation: 06/09/2020. Date of consultation: 06/09/2020 
Havryliuk Liudmyla, Drozd Valentyna, Nenia Olena, Kyslyi Anatolii y Andrii Niebytov

578 Systemic approach to the choice of optical methods of forensic examination of micro-objects

KYSLYI, Anatolii; PYSMENNA, Mariia; KOLOMOIETS, Oleksandr; VOLOBUIEVA, Olena; DAVYDENKO, Valerii. 2020. "Educational Processes of Training, Retraining and Advanced Training of Private Detectives in Ukraine" In: Cuestiones Políticas. Vol. 38, No. 66, pp. 42135. Available online. In: https://produccioncientificaluz.org/index.php/ cuestiones/article/view/34336. Date of consultation: 06/09/2020.

LACEY, Alan (ed.). 1999. Light Microscopy In Biology: A Practical Approach (Practical Approach Series). In: OUP . Oxford, Great Britain.

LANDSBERG, Hrihorii. 2000. Optics. In: FIZMATLIT. Moscow. Available online. In: https://www.twirpx.com/file/41359/. Date of consultation: 06/09/2020.

LEVSHIN, Leonid; SALETSKYI, Aleksandr. 1994. "Optical methods for studying molecular systems. Part 1. Molecular spectroscopy” In: MSU. Moscow, Russia.

LINCH, Charles; PRAHLOW, Joseph. 2008. "Microscopical examination of particles on smoked cigarette filters" In. Forensic science, medicine, and pathology. Vol. 4, No. 4, pp. 228-233. Available online. In: https://doi. org/10.1007/s12024-008-9053-9. Date of consultation: 06/09/2019.

LISICHENKO, Vitaliy. 1979. Using data from natural and technical sciences in investigative and judicial practice. Higher school. Kyiv, Ukraine.

MITRICHEV, Vitaliy. 2003. Fundamentals of forensic examination of materials, substances and products. In: Peter. St. Petersburg. Available online. In: https://royallib.com/book/mitrichev_vitaliy/osnovi_ kriminalisticheskogo_issledovaniya_materialov_veshchestv_i_izdeliy_iz_nih.html. Date of consultation: 06/09/2019.

NENIA, Olena. 2010. "Issues of legal regulation of the use of scientific and technical means and methods of criminology" In: Bulletin of Academy of Advocacy of Ukraine. Vol. 2, No.18, pp. 75-80.

NENIA, Olena. 2016. Optical methods of forensic examination of micro-objects. $\mathrm{PhD}$ Dissertation. National Academy of Internal Affairs. Available online. In: http://elar.naiau.kiev.ua/bitstream/123456789/1409/1/nenya_dis. pdf. Date of consultation: 06/09/2019.

UKRAINE. ORDER No. 53/5. 1998. About the statement of the Instruction on appointment and carrying out of forensic examinations and expert researches and Scientific and methodical recommendations concerning preparation and appointment of forensic examinations and expert researches. Official Gazette of the Verkhovna Rada of Ukraine, Kyiv, Ukraine, October 08, 1998. Available online. In: https://zakon.rada.gov. ua/laws/show/z0705-98\#Text. Date of consultation: 06/09/2019. 
PALENIK, Skip. 2013. Modern Trace Evidence Analysis and its Application to the Forensic Study of Soil, Sand and Dust. 10.3997/22144609.20131920. Available online. In: https://www.researchgate.net/ publication/266632767_Modern_Trace_Evidence_Analysis_and_its_ Application_to_the_Forensic_Study_of_Soil_Sand_and_Dust. Date of consultation: 06/11/2020.

PENTIN, Yurii; VILKOV, Lev. 2003. "Physical research methods in chemistry (Structural methods and optical spectroscopy)" In: Mir, AST. Moscow, Russia.

PRYSTUPA, Vadym; ZHUK, Borys. 2005. Examination of elemental composition of soils by X-ray fluorescence analysis. In: SSRFC of the MIA of Ukraine. Kyiv. Available online. In: https://zakon.rada.gov.ua/ laws/show/v1826323-11\#Text. Date of consultation: 06/09/2019.

SALTEVSKYI, Mikhail; LUKASHEVYCH, Vitaliy. 1987. "Micro-objects and scent traces" In: KHS of MIA of the USSR. Kyiv, Ukraine.

SALTEVSKYI, Mikhail. 1980. "Collecting forensic information by technical means during preliminary investigation” In: KHS. Kiev, Ukraine.

SKRYPKO, Halyna. 2012. "Methodology for determining the specific identification characteristics of natural fibres, identification of the fibrous composition of threads, textile materials and products from them by polarization microscopy" In: Examination of Fibers and Fibrous Materials: Method. SSRFC of the MIA of Ukraine. Kyiv, Ukraine.

TATARNIKOVA, Tetiana. 2017. Elements of quality assurance of forensic science activity as. Available online. In: tools of standardization. http://elar.naiau.kiev.ua/bitstream/123456789/3691/1/\%Do\%A2\% Do\%Bo\%D1\%82\%Do\%Bo\%D1\%80\%Do\%BD\%D1\%96\%Do\%BA\% Do\%BE\%Do\%B2\%Do\%Bo\%20\%Do\%A2\%Do\%B5\%D1\%82\%D1\% 8F\%Do\%BD\%Do\%Bo\%20\%Do\%9E\%Do\%BB\%Do\%B5\%Do\%BA\% D1\%81\%Do\%Bo\%Do\%BD\%Do\%B4\%D1\%80\%D1\%96\%Do\%B2\% Do\%BD\%Do\%Bo.pdf. Date of consultation: 06/09/2019.

TOVMASIAN, Arutiun., et al. 2005. "Validation of gas chromatography-mass spectrometry and UV spectrometric methods for quantification of buprenorphine according to requirements of ISO/IEC 17025: 2005" In: Theory and Practice of Forensic Examination and Criminalistics. Issue 18, pp. 351-359.

UKRAINE. 1960. Law 1001-05, of December 28, Criminal Procedure Code of Ukraine. Official Gazette of the Verkhovna Rada of Ukrainian SSR of December 1960, no. 2, p. 15. 
Havryliuk Liudmyla, Drozd Valentyna, Nenia Olena, Kyslyi Anatolii y Andrii Niebytov

580 Systemic approach to the choice of optical methods of forensic examination of micro-objects

UNITED STATES PRESIDENT'S COUNCIL OF ADVISORS ON SCIENCE AND TECHNOLOGY. 2016. Report to the president Forensic Science in Criminal Courts: Ensuring Scientific Validity of Feature-Comparison Methods. Available online. In: https://obamawhitehouse.archives.gov/ sites/default/files/microsites/ostp/PCAST/pcast_forensics_request_ for_information.pdf. Date of consultation: 28/09/2019.

VOROBEY, Petro; FELYK, Vasil; NIEBYTOV, Andrii; MATVIICHUK, Valerii; VOROBEY, Olena. 2021. "Nature and Significance of the State's Criminal Law Policy" In: Amazonia Investiga, Vol. 10, No. 39, pp. 225-231. Available online. In: https://doi.org/10.34069/AI/2021.39.03.22. Date of consultation: 22/04/2021. 
Vol. 39 N $^{\circ} 69$

Esta revista fue editada en formato digital y publicada en julio de 2021, por el Fondo Editorial Serbiluz, Universidad del Zulia. Maracaibo-Venezuela 